\title{
Month of Seeding Effect on Low-Input Establishment of Cool- and Warm-Season Turfgrasses in Continental Transition Zone
}

\author{
Kenneth Lynn Diesburg and Ronald F. Krausz
}

Department of Plant, Soil Sciences, and Agriculture System, Southern Illinois University at Carbondale, Carbondale, IL 62901 USA.

Received: June 30, 2013 / Accepted: September 14, 2013

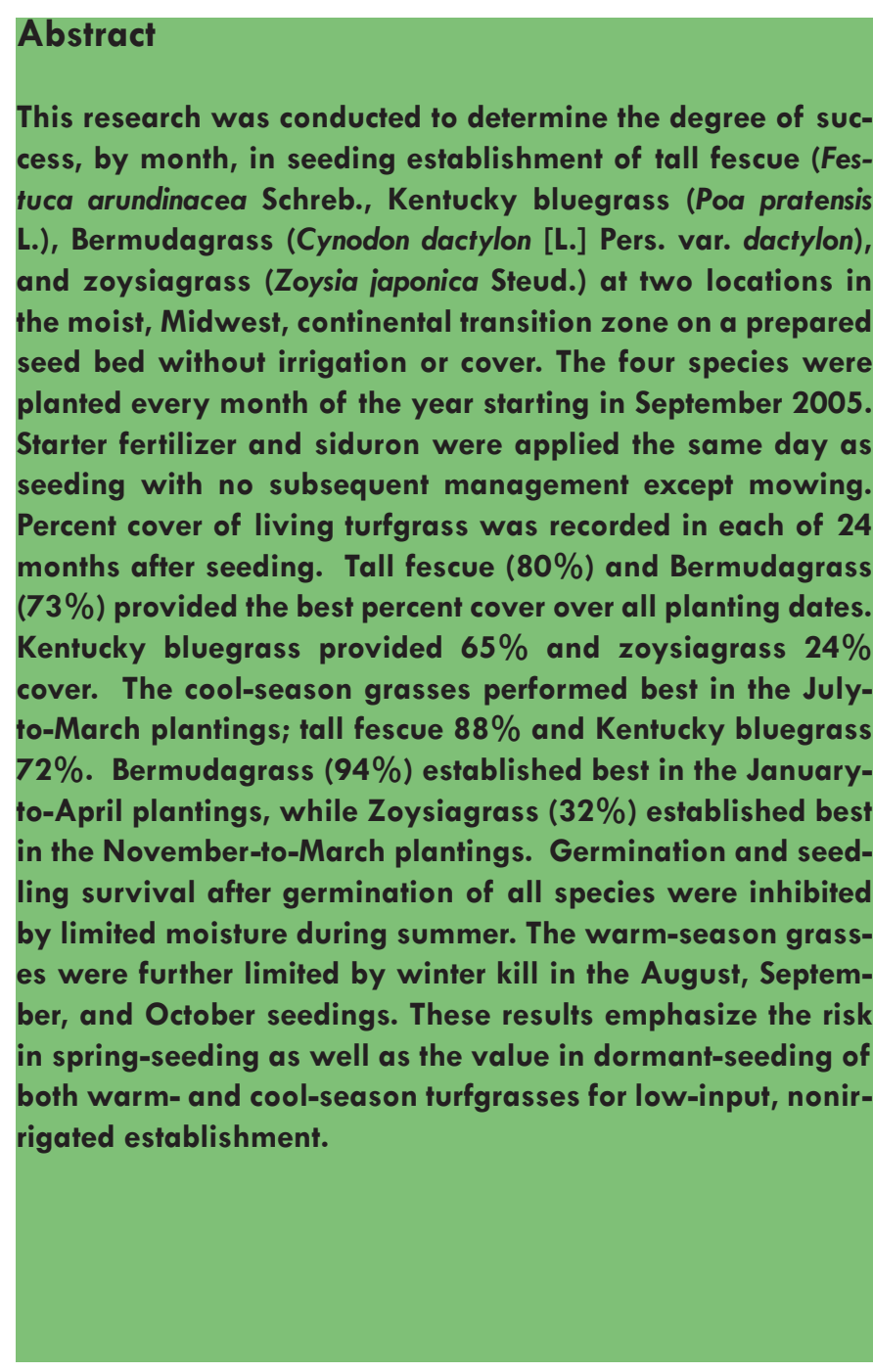

Introduction

Research long ago established early autumn as the ideal time to seed cool-season species (DeFrance and Simmons, 1951; Harrison, 1944) and early summer for the warm-season species (Johnson and Thompson, 1961). Hull (1948) reported that late fall seedings of cool-season grasses for southern Idaho rangelands, while providing stands superior to spring seedings, resulted in stands the following growing season that were inferior to early fall seedings. The first mention of dormant seeding, regardless of cool- or warm-season turfgrasses, was made by Musser (1962). Recent studies have addressed the best timing within seasons. Diesburg (1986) reported that dormant seeding of Kentucky bluegrass in central lowa in November produced better stands the following growing season than those of $\mathrm{De}$ cember, February, or March, while September seeding resulted in the best stands. Reicher et al. (2000) found that dormant seeding of tall fescue and Kentucky bluegrass in northern Indiana during November, December, or March provided better stands the following August than those of April or May seedings. Green et al. (1974) included tall fescue, Kentucky bluegrass, and Bermudagrass in a dormant seeding study of many species. Done in both the mountains and coastal plain of Virginia, they recorded favorable results from tall fescue and Kentucky bluegrass but not from Bermudagrass. The plots were covered with over 1,500 $\mathrm{kg} \mathrm{ha}^{-1}$ wood fiber cellulose mulch. Contrarily, Shaver, et al. (2006) obtained favorable results from winter dormant seedings of Bermudagrass. Their plots were covered with six mm of sand. Patton, et al. (2004) found in an irrigated study that Bermudagrass and zoysiagrass seeded May 15 provided enough cover to survive the following winter. Dudeck and Peacock (1982) found in Florida that winter dormant seeding of bahiagrass (Paspalum notatum Flugge) produced greater than

*Corresponding author: diesburg@siu.edu 
$90 \%$ cover during the following growing season.

In all seedling establishment, there is the necessity of soil surface moisture during emergence of the seed radical and the subsequent initial expansion of the seminal root system. Without properly timed moisture, you risk losing the stand. There are many situations, however, where irrigation is not possible as in right-of-way, large lawn, range and pasture, and parks. These are common examples of an ever-growing topic in turf research, Low Input Sustainable Turf. Even in conventional turf management, the professional would prefer to have a reliable amount of soil moisture to eliminate any need for irrigation. With these points in mind, it would be useful to know the degree of success possible with winter dormant seeding, not only which turfgrass species, but also which months within a region would be best suited to non-irrigated, low-input establishment. The objective of this study, therefore, was to compare establishment from monthly seedings, within an entire year, of the dominant turfgrass species in climates typical of the moist midwest transition zone of North America, which includes southeast Missouri, southern Illinois, and southern Indiana.

\section{Materials and Methods}

Two locations were chosen to represent climates and soils typical of the northern and central portions of the moist midwest transition zone. Belleville, Illinois (North location) is in the northern side of 6a hardiness zone (Cathey, 1990) with a Weir Silt Loam soil, and Carbondale, Illinois (South location) is in the southern side of 6 a with a Hosmer Silty Clay Loam. Both locations had been supporting tall fescue utility turf for several years prior to the experiment and had received no supplemental fertilizer for at least the previous four years. After a preliminary application of nonselective weed control with glyphosate, the sites were tilled and harrowed during August 2005 for the first monthly seeding in September. One cultivar of each of four species was chosen based on seed availability in that region and proven performance in the moist midwest transition zone (Morris, 2005 to 2007). Tall fescue (Festuca arundinacea, Schreb) 'Bingo' at $391 \mathrm{~kg} \mathrm{ha}^{-1}$ (8 lb $1000 \mathrm{sq} \mathrm{ft}^{-1}$ ), Kentucky bluegrass (Poa pratensis L) 'North Star' at $146 \mathrm{~kg} \mathrm{ha}^{-1}$ (3 lb $1000 \mathrm{sq} \mathrm{ft}^{-1}$ ), hulled Bermudagrass (Cynodon dactylon [L.] Pers. var. dactylon) 'Mirage' at $98 \mathrm{~kg} \mathrm{ha}^{-1}$ (2 lb $1000 \mathrm{sq} \mathrm{ft}^{-1}$ ), and Zoysiagrass (Zoysia japonica Steud.) 'Zenith' at $146 \mathrm{~kg} \mathrm{ha}^{-1}$ (3 lb $1000 \mathrm{sq} \mathrm{ft}^{-1}$ ) (McCarty, 2005), were seeded separately into $1.5 \mathrm{~m} 2$ plots each month from September 2005 through August 2006. At each monthly seeding the soil surface was loosened to a 3-cm depth with a garden rake. The tall fescue and Kentucky bluegrass were incorporated lightly with the back of a spring-steel-tined leaf rake. The Bermudagrass and zoysiagrass were left at the soil surface. Incorporation of the Bermudagrass seed (hulls removed) would have buried them too deeply due to their small size. Zoysiagrass stands are severely compromised when the seed, having an irradiance requirement for germination, are incorporated into the soil. Treatments were arranged in a split-plot design with three replications, species randomly assigned within a replication block as whole plots, and months of seeding randomly assigned within species as sub-plots. In order to inhibit initial competi- tion from weed seedlings, the preemergent herbicide, siduron (Tupersan), was applied to each plot the same day of seeding, except those of Bermudagrass to which it is phytotoxic. Field grade fertilizer (12-12-12, N-P-K) was chosen on the basis of availability as a starter fertilizer applied just before seeding at

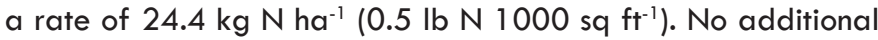
inputs were applied at any point except to maintain turf at 5.1 $\mathrm{cm}$ clip without removal of clippings. Percent live cover was recorded monthly by visual estimation. Monthly precipitation and evaporation rates at the two locations through the duration of seedings and recording of data are provided in Figure 5 (IIlinois State Water Survey), showing the overall gain and loss of water through the seasons. Average monthly maximum and minimum temperatures at two locations are provided in Figure 6 (Illinois State Water Survey). Since there were only minute variations in average monthly temperatures between them, a single line represents both locations. Means, analyses of variance, and tests of significance ( $\alpha=0.05$ ) were calculated for each monthly set of data using Statistical Analysis Systems (SAS). The analysis of data combined from both locations revealed significant firstand second-order interactions of species and month-of-seeding with location for every monthly set of data. Therefore, data were analyzed separately by location. Figures 1 to 4 provide graphic representation of establishment after monthly seeding. In several cases establishment from monthly seedings were so similar that they could not be distinguished from one another in the graph. Correspondingly, there were no significant differences detected among those months. Therefore, for the sake of clear presentation, the means of similar establishments after monthly seedings were averaged into one series of means and are represented by one line in a graph.

\section{Results and Discussion}

At both locations (Tables 1 and 2) there were significant differences in turf percent cover among species and months-ofseeding. In addition, there was a significant species-by-month interaction during all months except October 2007 at the South Location.

\section{Tall Fescue}

\section{North Location}

The September seeding (Fig. 1 a) provided excellent establishment (98\% cover by June 2006) as did the June, July, and August seedings; June (94\%), July (100\%), and August (94\%) by May 2007. Germination of all those summer seedings occurred at the same time during September of that year. Through the summer, rains were infrequent enough (Fig. $5 a$ ), and subsequent soil moisture was fleeting enough to prevent their germination until fall. They were essentially summer-dormant seedings. Germination from the October seeding although immediate, did not allow time for the tall fescue to mature enough to provide full cover $(69 \%)$ through the winter months. This effect of reduced stand carried over through the duration of the study since tall fescue is not a spreading species. The winter dormant seedings 
Table 1. Tests of significance from analyses of variance of main effects and interactions of four turfgrass of seeding on percent turf cover at Belleville, Illinois (North location).

\begin{tabular}{|c|c|c|c|c|c|c|c|c|c|c|c|c|c|}
\hline & & 2005 & & & & & & & & & & & \\
\hline Source & Oct. & Nov. & Dec. & Jan. & Feb. & Mar. & Apr. & May & Jun. & Jul. & Aug. & Sept. & Oct. \\
\hline Species S) & $* *$ & $* * *$ & $* * *$ & $* * *$ & *** & *** & $* * *$ & $* * *$ & $*$ & ** & ** & $* *$ & ** \\
\hline Mo. Seeded (M) & $* * *$ & $* * *$ & $* * *$ & $* * *$ & $* * *$ & $* * *$ & $* * *$ & $* * *$ & $* * *$ & $* * *$ & $* * *$ & $* * *$ & $* * *$ \\
\hline$S \times M$ & $* * *$ & $* * *$ & $* * *$ & $* * *$ & $* * *$ & $* * *$ & $* * *$ & $* * *$ & $* * *$ & $* * *$ & $* * *$ & $* * *$ & $* * *$ \\
\hline LSDt: $S \times M$ & 4.7 & 4.0 & 3.3 & 4.7 & 5.5 & 5.5 & 7.0 & 14.6 & 19.0 & 17.1 & 20.0 & 20.7 & 22.3 \\
\hline
\end{tabular}

* Significant $\mathrm{F}$ test at the 0.05 level of probability

** Significant $\mathrm{F}$ test at the 0.01 level of probability

*** Significant $F$ test at the 0.001 level of probability

$\dagger$ Least Significant Difference $(\alpha=0.05)$ among species by month-of-seeding means

Table 2. Analyses of variance of main effects and interactions of four turfgrass species and twelve months of seeding on percent turf cover at Carbondale, Illinois (South location).

\begin{tabular}{|c|c|c|c|c|c|c|c|c|c|c|c|c|c|}
\hline & \multicolumn{3}{|c|}{2005} & \multicolumn{10}{|c|}{2006} \\
\hline Source & Oct. & Nov. & Dec. & Jan. & Feb. & Mar. & Apr. & May & Jun. & Jul. & Aug. & Sept. & Oct. \\
\hline Species S) & **** & **** & **** & **** & **** & $* * *$ & $* * *$ & **** & *** & $* * *$ & $* *$ & $* *$ & ** \\
\hline Mo. Seeded (M) & $* * *$ & $* * *$ & $* * *$ & $* * *$ & $* * *$ & $* * *$ & $* * *$ & $* * *$ & $* * *$ & $* * *$ & $* * *$ & $* * *$ & $* * *$ \\
\hline$S \times M$ & $* * *$ & $* * *$ & $* * *$ & $* * *$ & $* * *$ & $* * *$ & $* * *$ & $* * *$ & $* * *$ & $* * *$ & $* * *$ & $* * *$ & $* * *$ \\
\hline LSDt: $S \times M$ & 4.2 & 8.5 & 6.9 & 6.1 & 6.9 & 6.1 & 12.4 & 22.5 & 18.9 & 23.6 & 26.2 & 30.1 & 31.2 \\
\hline
\end{tabular}

\begin{tabular}{|c|c|c|c|c|c|c|c|c|c|c|c|c|}
\hline & \multicolumn{2}{|c|}{2006} & \multicolumn{10}{|c|}{2007} \\
\hline Source & Nov. & Dec. & Jan. & Feb. & Mar. & Apr. & May & Jun. & Jul. & Aug. & Sept. & Oct. \\
\hline Species S) & $* * *$ & $* * *$ & $* * *$ & *** & $* * *$ & $* * *$ & $* * *$ & *** & $* * *$ & $* *$ & $* *$ & $*$ \\
\hline Mo. Seeded (M) & $* * *$ & $* * *$ & $* * *$ & $* * *$ & $* * *$ & $* * *$ & $* * *$ & $* * *$ & $* * *$ & $* * *$ & $* * *$ & $* * *$ \\
\hline$S \times M$ & $* * *$ & $* * *$ & $* * *$ & $* * *$ & $* * *$ & $* * *$ & $* * *$ & $* * *$ & $* * *$ & $* * *$ & $*$ & NS $\ddagger$ \\
\hline LSD+: $S \times M$ & 29.8 & 27.7 & 26.5 & 25.6 & 24.3 & 14.3 & 19.6 & 24.5 & 26.4 & 31.0 & 33.7 & \\
\hline
\end{tabular}

* Significant $\mathrm{F}$ test at the 0.05 level of probability

** Significant $\mathrm{F}$ test at the 0.01 level of probability

*** Significant $\mathrm{F}$ test at the 0.001 level of probability

+ Least Significant Difference $(\alpha=0.05)$ among species by month-of-seeding means

$¥ \mathrm{NS}$, not significant at the 0.05 level of probability

and March were similar to one another one year after seeding; November (81\%), December (85\%), January (78\%), February $(72 \%)$, and March (69\%), and were thus, as effective as the October seeding. Note that germination from all the winter dormant seedings occurred in March. Summer covers after the April and May seedings were severely restricted by $9 \%$ to $21 \%$. Subsequent recovery from those months of seeding never surpassed $67 \%$ cover.

\section{South Location}

The fall seedings (Fig. 1b) performed similarly to those at the North location with the exception of their greater decline in percent cover during the summer months. The September seeding, having more maturity, declined an average of $24 \%$ from $95 \%$ in June to $71 \%$ in September 2006, then recovered to $90 \%$ by May 2007. The October seeding, with less maturity, declined $30 \%$ from $69 \%$ in June to $39 \%$ in July 2006 , then recovered to $77 \%$ by May 2007 . The winter dormant and March seedings behaved similarly to those of the Northern location, again, with the exception of their more severe decline in response to summer stress (Fig. 1 b) showing $25-46 \%$ reductions in cover from May to August 2006. The April seeding differed from that of the North location, establishment behaving similarly to those of the dormant and March seedings. The May and June seedings failed, reaching only $8 \%$ and $32 \%$ cover, respectively due to temporarily inadequate soil surface moisture immediately following germination. The July and August seedings performed similarly to those at the North location site remaining dormant until September germination.

\section{Kentucky Bluegrass}

\section{North Location}

All of the monthy seedings (Fig. 2a) displayed best percent cover during their subsequent April to July (51-91\%). Establishment from the September and October seedings was slow during fall 2005 , but maximized to $83 \%$ and $71 \%$ cover by May 2006. The September cover subsequently sustained itself at $47 \%$ through a dry late summer and fall, while that of the October seeding thinned to $23 \%$. The winter dormant and March seedings germinated in April expanding to covers of $51-72 \%$ by July. Their cover also diminished through the dry late summer and fall to $28 \%$. The April, May, June, and August seedings resulted in a mixture of dormant seeds and partially lost 


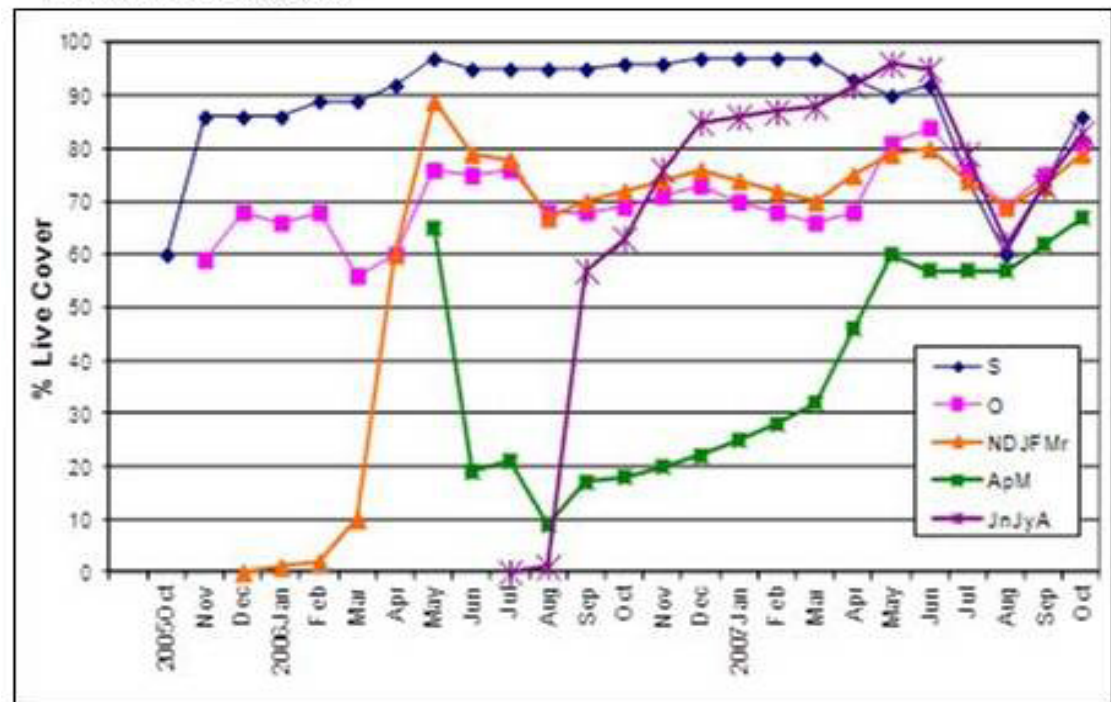

b. Tall Fescue Seedings, South

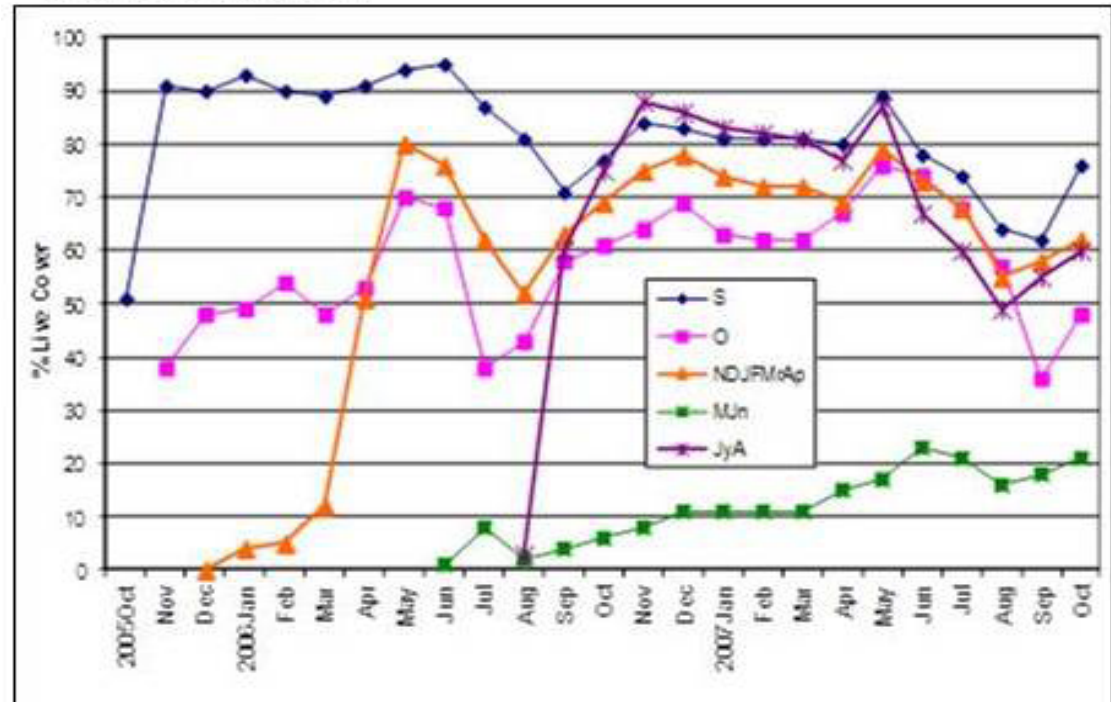

Figure 1. Establishment of tall fescue at two transition zone locations, (a) North (Belleville, IL) and (b) South (Carbondale, IL), after monthly seedings through an entire year. LSD is the Least Significant Difference between and among means for that month.

stands through summer and fall. Surviving plants established slowly through fall and winter and maximized by June 2007 at an average of $54 \%$ cover. The July seeding received enough timely rain to establish a $27 \%$ cover into winter which expanded rapidly during March to $90 \%$ cover by April 2007.

\section{South Location}

Expansion of cover was less focused in spring as it was at the North location due to more autumn rain events at the south location (Figs. 5a, 5b). The September seeding (Fig. 2b) reached $36 \%$ cover by November 2005 , expanded gradually through the winter, and had $64 \%$ cover by May 2006, which it never surpassed throughout the rest of the study. The October through March seedings germinated during March established rapidly into May to an average maximum cover of $44 \%$, then dimin- ished severely through summer to an average of $12 \%$. December seeding was unique in its maximum cover of $86 \%$ by May previous to its summer decline to $30 \%$. Fall 2006 growth was strong allowing expansion to $76 \%$ in the December seeding and $47 \%$ in the other months of seeding. The May and June seedings failed while the April seeding had enough surviving plants after summer stress to establish as much cover as those of the July and August seedings, averaging $32 \%$ by November 2006. Those stands expanded further to $65 \%$ by June 2007 .

\section{Bermudagrass}

\section{North Location}

This species provided excellent cover from all the monthly seedings of October to June (Fig. 3a). The September 2005 


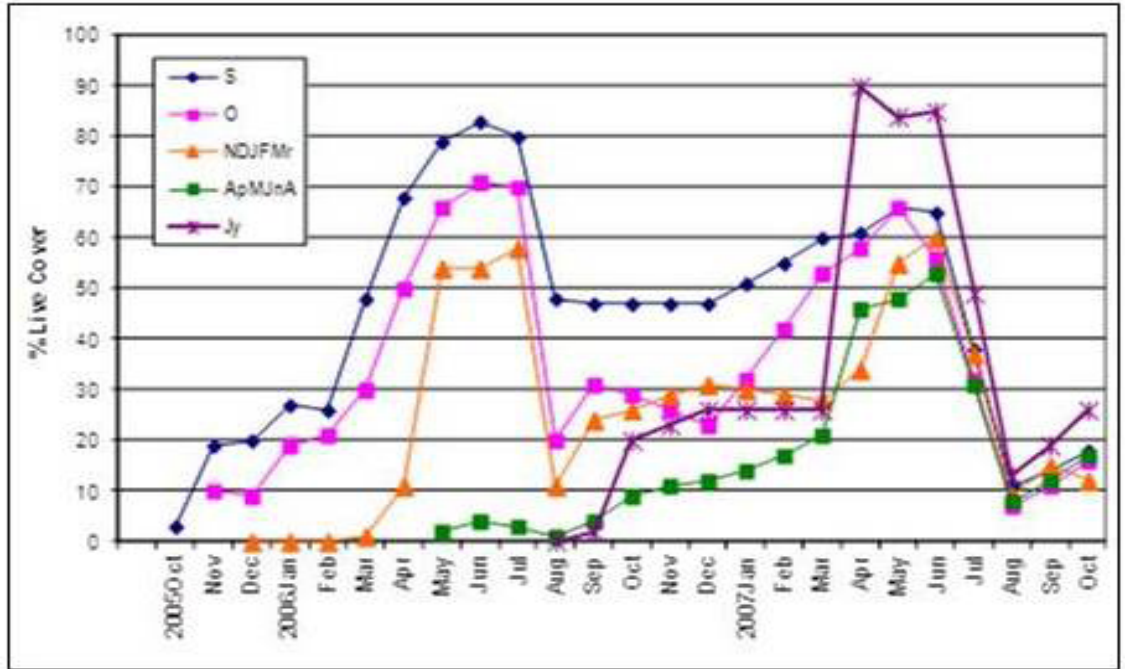

b. Kentucky Bluegrass Seedings, South

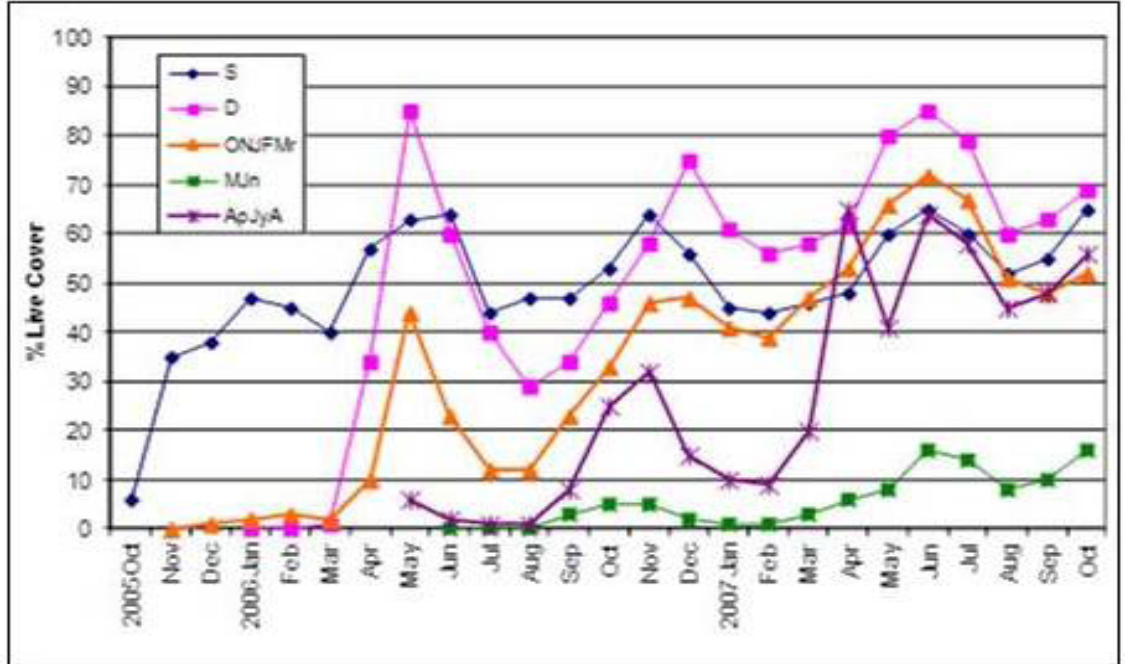

Figure 2. Establishment of Kentucky bluegrass at two transition zone sites, (a) North (Belleville, IL) and (b) South (Carbondale, IL), after monthly seedings through an entire year. LSD is the Least Significant Difference between and among means for that month.

seeding established quickly reaching $77 \%$ cover by November. It survived the winter but never achieved the cover in the October to June seedings, reaching $90 \%$ by October 2006 . The October to March seedings all germinated during April 2006, while the April, May, and June seedings germinated quickly within their respective month. Almost full covers were achieved from the October to June seedings ranging from 81 to $100 \%$ through the subsequent fall to spring. The July seeding, while germinating quickly and covering to $94 \%$ by October, lost cover through winter. The August seeding failed with almost all juvenile plants dying through the subsequent winter. Its few surviving plants spread enough to achieve 97\% cover by August 2007.

\section{South Location}

Establishment was not as successful as at the North location. The
September and October 2005 seedings (Fig. 3b) failed due to winter kill of juvenile plants. Success of the dormant seedings was variable. All dormant seedings germinated in April with maximum cover achieved by October. Average maximum cover of the November, December, and January seedings (66\%) was not as great as the average of the February, March, and April seedings (96\%). The May, June, July, and August seedings germinated in hot conditions with variable soil moisture, losing stand, achieving $56 \%$ by October. All seedings survived the 2006/2007 winter and recovered well in 2007.

\section{Zoysiagrass}

\section{North Location}

All monthly seedings of zoysiagrass from September to April 


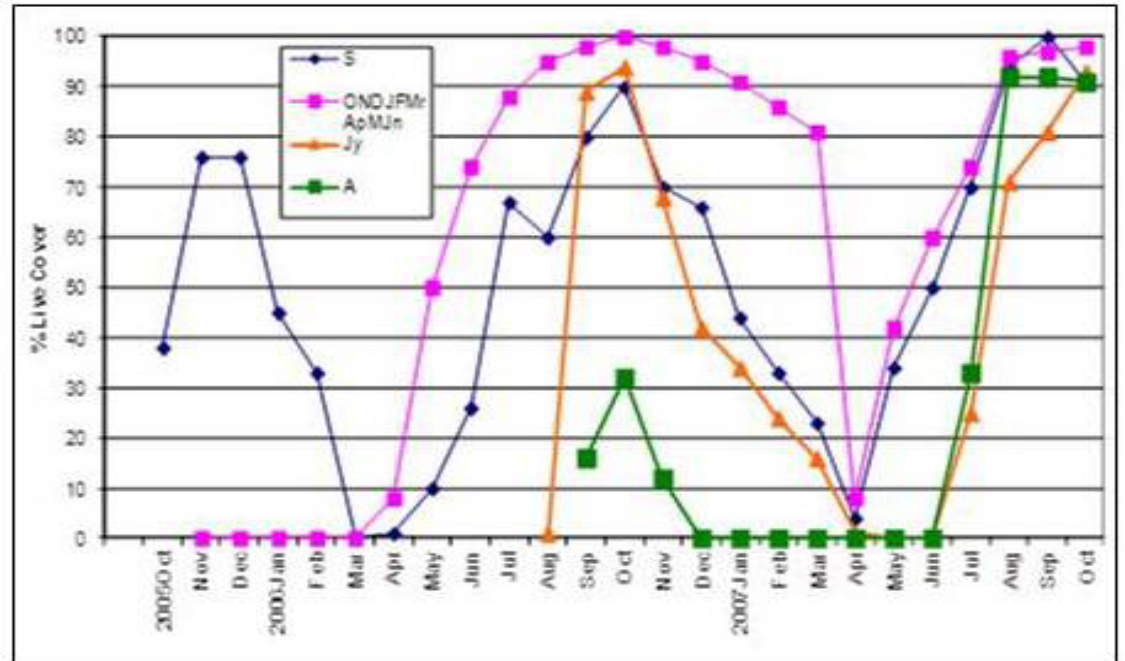

b. Bermudagrass Seedings, South

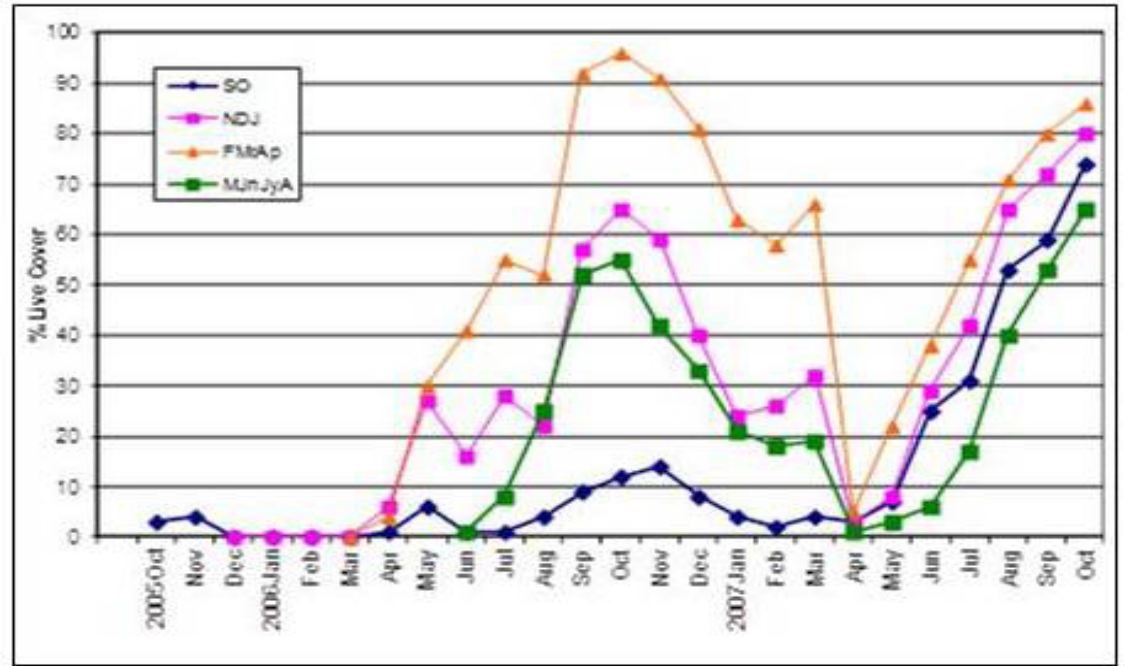

Figure 3. Establishment of Bermuda at two transition zone sites, (a) North (Belleville, IL) and (b) South (Carbondale, IL), after monthly seedings through an entire year. LSD is the Least Significant Difference between and among means for that month.

(Fig. 4a) germinated in April and achieved maximum covers by October 2006, as follows: September and October averaging $82 \%$, November, January, February, March, and April averaging $61 \%$, and December and May averaging 40\%. All three summer seedings failed due to loss of seedling stand from soil surface drought.

\section{South Location}

As with Bermudagrass, seedings were not as successful as at the North location. September and October seedings (Fig. 4b) germinated and died due to soil surface drought after seedling emergence. Only a few seedlings established in the November, December, January, and February seedings, experiencing strong winter annual weed competition, reaching only $2 \%$ cover by May, then finally achieving $15 \%$ in the latter half of 2006 after the winter annuals had died. The March seeding was the most successful reaching $7 \%$ cover through the winter annual weed competition, then achieving $57 \%$ cover by November 2006 . The April, May, June, July, and August seedings failed due to soil surface drought.

\section{Conclusion}

Figures $1 \mathrm{a}$ to $4 \mathrm{~b}$ portray the quick and persistent dominance of tall fescue, the quick but winter-weak dominance of bermudagrass, the high degree of variability in Kentucky bluegrass presence, and the slow but persistent increase of zoysiagrass toward dominance. These differences come as no surprise as they are characteristic of the species. The surprising thing is the months of seeding that brought about the best establishment.

All of these four species have their place in Low Input Sustainable Turf in the transition zone. They have all persisted very well in the transition zone for decades at minimal to no 


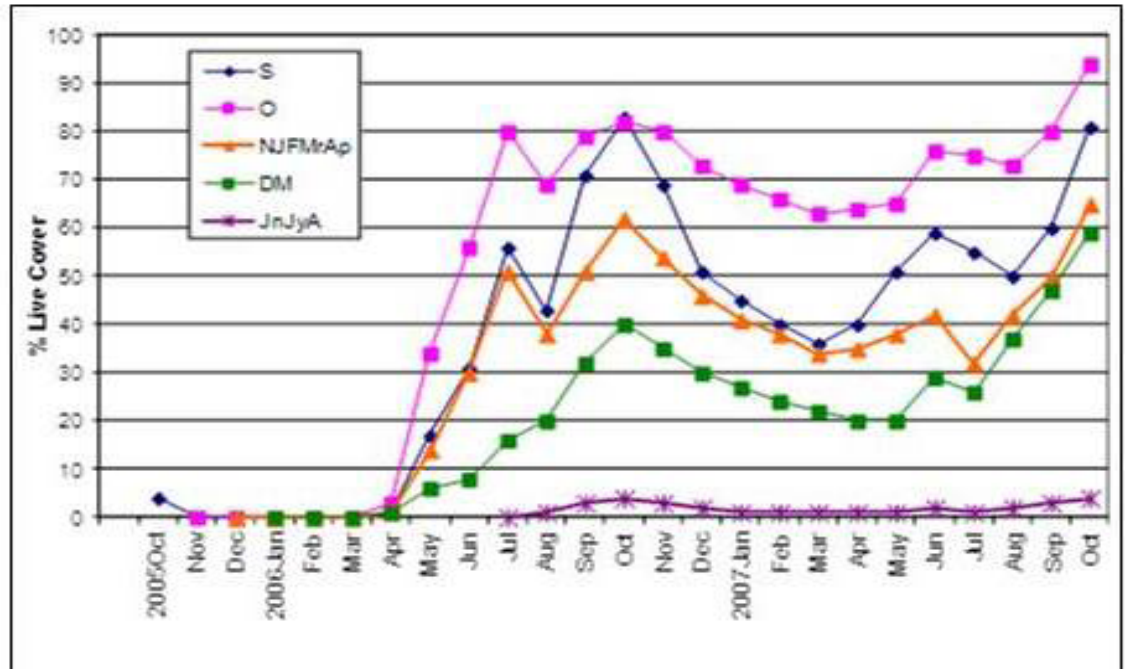

b. Zoysiagrass Seedings, South

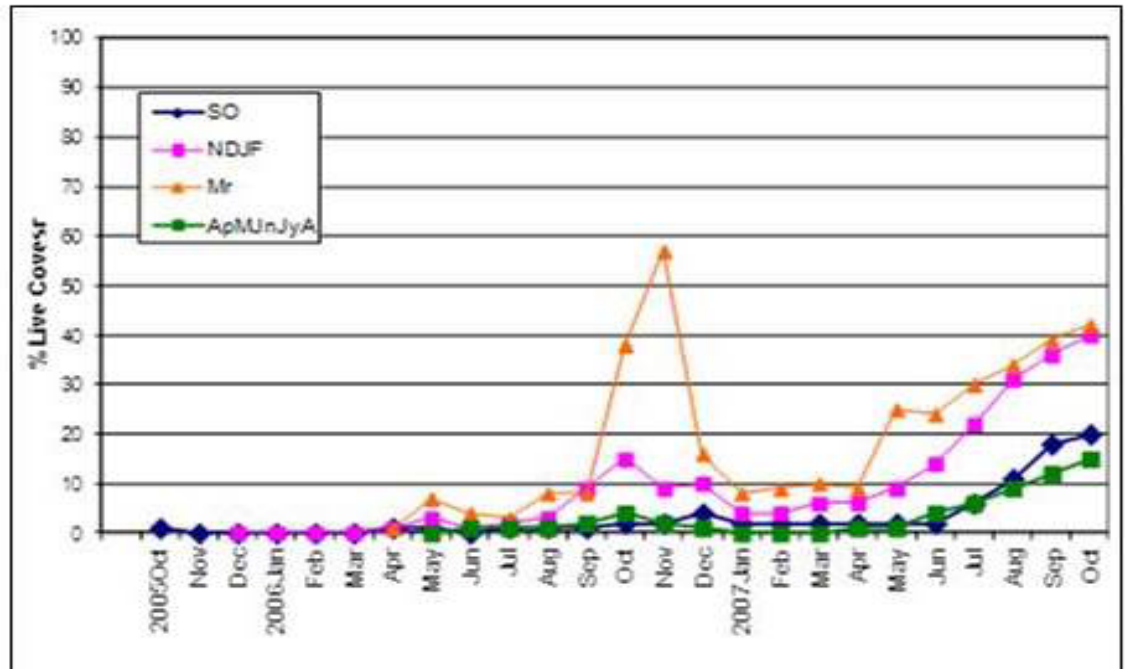

Figure 4. Establishment of Zoysia at two transition zone sites, (a) North (Belleville, IL) and (b) South (Carbondale, IL), after monthly seedings through an entire year. LSD is the Least Significant Difference between and among means for that month.

inputs except for mowing. Within their respective niches, they are commonly found to provide turf of acceptable quality for a portion of the year. Given that they are persistent species for Low Input Sustainable Turf, synchronization of management with growing seasons is paramount in order to optimize their capacities. For success in low-input establishment, timing is everything. The water and temperature conditions through the duration of this research, represented in Figures 5 and 6, were typical for the region. Precipitation through winter and spring is ample in recharging soil moisture. Figures $5 \mathrm{a}$ and $5 \mathrm{~b}$ indicate the north location receiving less winter precipitation than the south location in 2005/2006. Even so, seed germination and seedling establishment in winter dormant seedings appears to have been unaffected between the two locations. The disparity between precipitation and evapotranspiration during summer months is common.

The tall fescue and Kentucky bluegrass results correspond with previous research, showing the advantage of seeding coolseason grasses in early fall, September, while the days are still warm, the nights are beginning to cool, soil moisture does not evaporate so rapidly, and rains will become more frequent during middle fall (Fig. 5). The month previous to that time of year, August, provides excellent opportunity to prepare the seed bed since the soils are drier and rains more sparse. The data contradict, however, our recommendation to plant in spring as a second choice. From these transition zone data, the best second choice would be seeding any month other than April or May with March and June being marginal. During that early part of the growing season there is ample moisture to get the seeds germinated, but not enough to get the seedlings established and plants mature enough to withstand the rigors of summer. A safer approach is winter dormant seeding; getting the seed in place during any part of the moist, cold season, any month November to March, thus providing the critical two to three months needed after ger- 

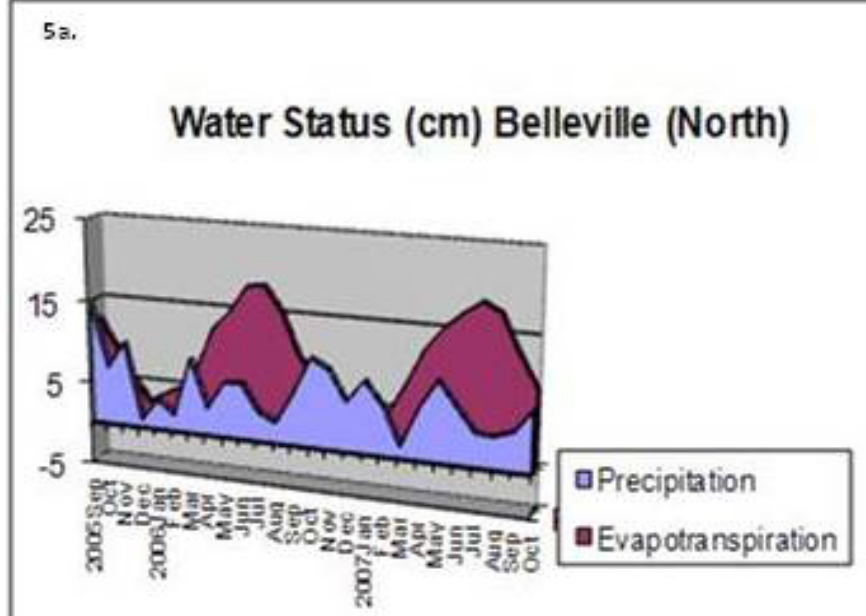

Water Status $(\mathrm{cm})$ Carbondale (South)

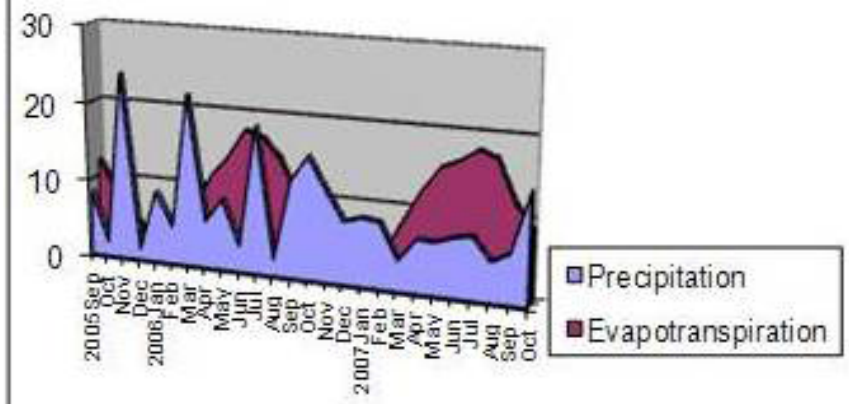

Figure 5. Monthly precipitation and evaporation rates at two locations through the duration of seedings and recording of data, showing the overall gain and loss of water through the seasons.

mination in early spring for at least some degree of plant maturation before summer. July and August are also recommended for summer dormant seeding. Rains do occur during late summer in the transition zone, but with low frequency and short duration. That condition, combined with the rapid rate of water evaporation during the excessive summer heat (Figs. 5 and 6), does not allow, in most cases, the seed enough time to germinate, and it remains dormant.

The bermudagrass and zoysiagrass results contradict previous research which indicates the seeding of warm-season grasses when it is warm during late spring or early summer. That research contains the assumption that irrigation will be supplied if needed. Low input establishment assumes no irrigation is applied. Granted, the warmth is needed but not the pervasive and unpredictable droughts that accompany the warm season. Additionally, by the time we seed in late spring or early summer, the warm-season annual weeds already have had a head-start in germination and can emerge over night, asserting competi- tion against the vulnerable turfgrass seedlings, especially those of zoysiagrass. In this research, summer seedings provided, at best, marginal establishment, and at worst, complete failure. Contrarily, winter dormant seeding provided, at best, excellent establishment, and at worst, marginal establishment. The ideal situation is to have the seed in place before the warm temperatures arrive in spring. Evidence from this paper points to March as the best month for seeding bermudagrass and zoysiagrass in the continental transition zone. At that time, the soil temperatures needed for warm-season grass seed germination have not yet arrived and there is usually a break in the spring rains to allow seed bed preparation. The safest approach, however, would be to winter-dormant seed, taking advantage of the higher probability of utilizing favorable weather and soil conditions over a much longer period of time.

Among the species, tall fescue provided the most reliable low-input establishment throughout the year. Its establishment was inadequate in only three of the nine months; April, May, 


\section{Average Monthly Air Temperatures Belleville (North) and Carbondale (South)}

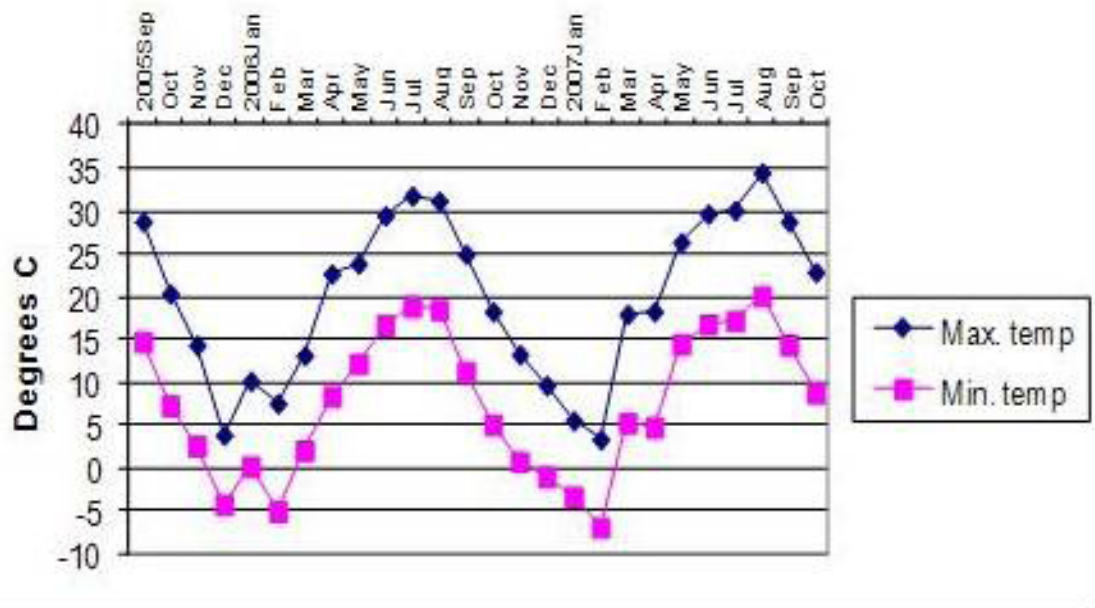

Figure 6. Average monthly maximum and minimum temperatures from two locations. There were only minute variations in average monthly temperatures between the two locations.

and June. Bermudagrass performed as well as tall fescue at the North location with only three substandard months: July, August, and October. At the South site, however, there were no months of seeding with complete cover, with February, March, and April as its best months of seeding. Greater moisture availability during the cool time of year interacted more reliably with the coolseason grasses than with the warm-season grasses. The slow germination and lack of vigor of Kentucky bluegrass without ample soil fertility prevented it from providing complete cover, even though May and June were the only months of seeding with complete failure to establish. Zoysiagrass was at an even greater disadvantage with its weak seedling and slow growth. At the North location, September and October were its best months of seeding while winter-dormant seeding and March seeding provided more relative success at both sites. June, July and August seedings failed. The long-term advantage of zoysiagrass for low-input turf could not be seen through the short duration of this study, since it takes longer for this species to become fully established.

\section{Acknowledgments}

This research was partially funded by the Illinois Turfgrass Foundation and the Southern Illinois Golf Courses Superintendents Association.

\section{References}

Cathey HM (1990) Plant Hardiness Zone Map. Revised, R. Jordon, 2001. USDA Misc. Pub. No. 1475.

DeFrance JA and JA Simmons (1951) Relative period of emergence and initial growth of turf grasses and their adaptability under field conditions. Proc. Am. Soc. for Hort. Sci. 57:439-442.

Diesburg KL (1986) Dormant seeding study. 1985 lowa Turfgrass Res.
Rpt. Publ. FG-451:65-66.

Dudeck AE and $\mathrm{CH}$ Peacock (1982) Dormant seeding of bahiagrass with cool season grasses in the winter. Proc. Fla. State Hort. Soc. 95:174-175.

Green JT, HD Perry, JM Woodruff, and RE Blaser (1974) Suitability of Cool- and Warm-season Species for Dormant Winter Seedings. p.557-568. In E.C. Roberts (ed.) Proc. Int. Turfgrass Res. Conf., $2^{\text {nd }}$, 19-21 June 1973. ASA and CSSA. Madison, WI.

Harrison CM (1944) Rough grasses for parks, highway, and recreational areas. Greenkeeper's Reporter 12:30-31.

Hull AC Jr (1948) Depth, season, and row spacing for planting grasses on southern Idaho range lands. J. Amer. Soc. Agron. 40:960-969.

Illinois State Water Survey: http://www.isws.illinois.edu.

Johnson CM and WR Thompson (1961) Fall and winter seeding of lawns. Mississippi Farm Research 24 (9): 4.

McCarty LB (2005) Best Golf Course Management Practices (2nd. ed). Pearson Education, Inc., Upper Saddle River, NJ. 868 pp.

Morris KN (2002) National Turfgrass Evaluation Program. $1997 \mathrm{Na}$ tional Bermudagrass Test. NTEP No. 02-7. USDA, Beltsville, MD.

Morris KN (2005) National Turfgrass Evaluation Program. $2000 \mathrm{Na}$ tional Kentucky bluegrass Test. NTEP No. 05-6. USDA, Beltsville, MD.

Morris KN (2006) National Turfgrass Evaluation Program. $2001 \mathrm{Na-}$ tional Tall Fescue Test. NTEP No. 06-5. USDA, Beltsville, MD.

Morris KN (2007) National Turfgrass Evaluation Program. $2002 \mathrm{Na-}$ tional Zoysiagrass Test. NTEP No. 07-2. USDA, Beltsville, MD.

Musser HB (1962) Turf management. McGraw Hill, New York.

Patton AJ, GA Hardebeck, DW Williams, and ZJ Reicher (2004) Establishment of bermudagrass and zoysiagrass by seed. Crop Sci 44: 2160-2167.

Reicher ZJ, CS Throssell, and DV Weisenberger (2000) Date of seeding affects establishment of cool-season turfgrasses. HortScience 35 (6): $1166-1169$.

Shaver BR, MD Richardson, JH McCalla, DE Karcher, and PJ Berger (2006) Dormant seeding bermudagrass cultivars in a transition-zone environment. Crop Sci. 46:1787-1792. 